\title{
ZEITGEIST IN SWIMSUITS ${ }^{1}$
}

\author{
Doç. Dr. Pınar GÖKLÜBERK ÖZLÜ*, Arezoo NASIRIAGHDAM** \\ *Gazi Üniversitesi, Sanat ve Tasarım Fakültesi, Moda Tasarımı Bölümü, ANKARA \\ ** Gazi Üniversitesi, Eğitim Bilimleri Enstitüsü, Giyim End. ve Giyim San. Eğt. Anabilim Dalı, ANKARA \\ pinarozlu@gmail.com / nasiriaghdam15@yahoo.com
}

\begin{abstract}
Swimming is unnatural activity for human beings. Unlike most of all other animals, we are not born with an instinct for swimming. However, ancient peoples who settled along seacoasts, lakeshores, and riverfronts had to learn to swim for gathering food and for simple survival. From this necessity, recreational swimming would have developed, both as an activity for individuals and as a group social practice. In many ancient civilizations, communal swimming and, later, bathing rituals were an integral part of society.

By the nineteenth century, a growing middle class in Europe and America began to enjoy vacation time at beaches and resorts with the convenience and efficiency of the expanding network of railroads. "Taking the waters" at a seashore meant wading out into the shallows buoyed by a floating canopy to prevent sunburn and to shield against prying eyes. Not until the mid-1800s did special forms of attire develop for public bathing. Even then, bathing costumes still closely resembled street clothing. But, such outfits were terrible weight burdens in wet, and drownings were common for the unwary. So, as more and more people began to request bathing costumes from their dressmakers, fashion styling diverged from daytime modes.

Clothing for swimming, bathing, and seaside wear has been an important and influential area of fashionable dress since the late nineteenth century. The evolution of swimming and bathing costumes has been closely associated with trends in mainstream fashion and advancements in textile technology, but has also reflected broader societal attitudes about personal hygiene, body exposure, and modesty, and whether or not it was appropriate for women to participate in active sports.

In this study, aimed to examine changes in model and material of swimsuits from the introduction to the end of twenties. Trial data obtained by the document analysis clothes illustrations, pictures and photographs and the material (fabric) is composed of information. The resulting visual analysis of data analysis models and colors in line with the spirit of the times (Zeithgeist), in terms of features was evaluated by examining the materials used. Nowadays fabric technology features and models demonstrate the importance and contribution to the sport of swimming in terms of work is considered to be important and interesting.
\end{abstract}

Key Words: fashion design, history, swimsuit, zeitgeist

${ }^{1}$ This article was presented orally in the $3^{\text {rd }}$ ISCS Conference, 24-26 May, 2014, Sarajevo 


\section{Introduction}

Fashion is noted for its continuous cycle of change and revival, which is sometimes linked to the philosophical zeitgeist theory. While it is often said that fashion is a reflection of the times, defining what is to be fashionable is not as straightforward as it may first appear. In order for something to be fashionable it should be contemporary relevance.

The term zeitgesit literally means `spirit of the times`. Fashion is a component of popular culture and in accordance with the principles of the zietgesit. Often reflects current political and cultural effects. It is subject to external forces that might include dominate events, ideas, attitudes, social groups and technologies(Hopkins, 2012:10). The zeitgeist theory views fashion as the collective aggregation of individual choices throughout society. These choices, which are both expressive and consumptive, converge on themes that reflect the milieu and social context of the times(Hemphill and Suk, 2009:111).

A swim wear, swimsuit, bathing suit, swimming suit, is an item of clothing designed to be worn by people engaging in a water-based activity or water sports, such as swimming, water polo, diving or during activities in the sun, such as sun bathing. Different types are worn by men, women, and children(http://tr.wikipedia.org). Swimwear has been around since the mid-1800's, when the improvements in rail travel made it easier for people to travel to water. The original swimsuits are a far cry from the suits of today.

Clothing for swimming, bathing, and seaside wear has been an important and influential area of fashionable dress since the late nineteenth century. The evolution of swimming and bathing costumes has been closely associated with trends in mainstream fashion and advancements in textile technology, but has also reflected broader societal attitudes about personal hygiene, body exposure, and modesty, and whether or not it was appropriate for women to participate in active sports.

Swimwear have gone through a vast amount of changes in the past hundred plus years. From long sleeved, long legged suits for men and baggy long sleeve dresses for women of the 1800's to the Speedo for men and bikini for women of today, the fashion of swimwear has changed dramatically according to the theory of zeitgeist, and it will continue to change in years to come (http://www.fragrancex.com).

\section{Materials and methods}

This inquriy is based on visual method and materials in qualititve research method. Qualitative research is aimed at gaining a deep understanding of a specific organization or event, rather a than surface description of a large sample of a population. It aims to provide an explicit rendering of the structure, order, and broad patterns found among a group of participants and materials(http://www.csulb.edu).

One of the central frontiers in the further development of qualitative method focuses on the involvement of visual methods and material in qualitative research designs. Visual methods are techniques that involve the acquisition and creation of images that can be used and interpreted to contribute insights into aspects of social and organizational behaviour (http://srmo.sagepub.com).

Visual data are of growing importance for qualitative research, because a wide array of visual forms is now increasingly used in almost all spheres of everyday life. Images, pictures, and other visual representations, and particularly the availability and omnipresence of video 
recordings, are profoundly transforming everyday culture, knowledge production, and communication (http://www.esamidterm2012).

Materials of this study consist of images and illustrations. This materials are analized by using Visual content analysis technique. This technique identification and counting of events, characteristics, or other phenomena in visual data. Analyzed forms prepared in accordance with this purpose and visual date has been reviewed.

In the form of visual analysis the swimsit that used in 1850-200, are evaluted in terms of model features, color and pattern. fabric properties are evaluated in terms of the information obtained from the literature. The obtained information is classified according to the years that changes were noteworthy and presented in tables.

\section{Findings}

By the nineteenth century, a growing middle class in Europe and America began to enjoy vacation time at beaches and resorts with the convenience and efficiency of the expanding network of railroads. "Taking the waters" at a seashore meant wading out into the shallows buoyed by a floating canopy to prevent sunburn and to shield against prying eyes. Not until the mid-1800s did special forms of attire develop for public bathing. Even then, bathing costumes still closely resembled street clothing (Hill, 2004: 158). In this century, modesty prevailed over form and function. Women took to the water in long dresses made from fabric that wouldn't become transparent when submerged. To prevent the garments from floating up to expose any precious calf (or beyond, heaven forbid), some women are thought to have sewn lead weights into the hem to keep the gowns down ( http://www.smithsonianmag.com). 
Table 1. The 1850`s up 1910`s Swimsuits Analyses

\begin{tabular}{|c|c|c|}
\hline$p$ & $\begin{array}{l}\text { The } \\
\text { model } \\
\text { properties }\end{array}$ & $\begin{array}{l}\text { A high-necked, fitted bodice was worn with } \\
\text { a full, ankle-length skirt over voluminous } \\
\text { bloomers } \\
\text { (http://www.smithsonianmag.com). }\end{array}$ \\
\hline & $\begin{array}{l}\text { The } \\
\text { fabric } \\
\text { properties }\end{array}$ & $\begin{array}{l}\text { Most bathing costumes were made of stiff } \\
\text { taffeta, although wool was frequently used } \\
\text { in climates where waters were chilly even in } \\
\text { summer (Hill, 2004: 158). }\end{array}$ \\
\hline 30 & $\begin{array}{l}\text { The color } \\
\text { properties }\end{array}$ & $\begin{array}{l}\text { Dresses was in dark colors (which were less } \\
\text { revealing of the figure when wet) such } \\
\text { black, navy and plum, and enlivened by } \\
\text { jaunty details such as sailor collars and } \\
\text { braid trim in contrasting colors. }\end{array}$ \\
\hline http://inventors.about.com/od & $\begin{array}{l}\text { The } \\
\text { accessory } \\
\text { properties }\end{array}$ & $\begin{array}{l}\text { Hats, rubberized and oilcloth caps, and a } \\
\text { variety of turban- like head-wraps kept hair } \\
\text { neat and protected from salt water. Full- } \\
\text { length dark stockings kept the legs modestly } \\
\text { covered, and flat-soled bathing shoes, often } \\
\text { with ribbon ties crossing up the leg, } \\
\text { protected the feet and set off the ankles ( } \\
\text { Ward, 2005). }\end{array}$ \\
\hline
\end{tabular}

Nevertheless, as more and more women began to request bathing costumes from their dressmakers, fashion styling diverged from daytime modes. By the the beginning of the twentieth century, bathing suits had become lighter, with shorter overskirts and bloomers. Bodices were daringly sleeveless, some with décolleté necklines. Despite the proliferation of seaside resorts and lake retreats during the last quarter of the nineteenth century, though, the market for swimwear remained narrow. Retailers saw no great demand for the outfits, so only a few ready-towear makers attempted any mass production of swimwear. In the 1895 spring and summer edition of Montgomery Ward's catalog, hundreds of specialized garments were listed, including clothing specifically for dentists, barbers, and cooks, but not one item of swimwear. Vogue's pattern department did not feature a swimwear model until 1907 ((Hill, 2004: 158).

By the 1910s three significant social changes had occurred in America that helped broaden the appeal of recreational swimming for women. First, Henry Ford had made the Model T affordable to the masses beginning with its production in 1908, and in a short time, automobile excursions and vacations to the seaside or local lake resorts were enjoyed by 
wider socioeconomic classes. Second, the styling of the bathing suit, with its knee-length skirt and sleeveless bodice, had been a familiar image in the mass media and on public beaches for almost twenty years by this time, so the stigma of immodesty had diminished considerably. Third, a new self-image of sex appeal was experienced by young women in this decade (Hill, 2004: 159). As a result of these social shifts, the market for bathing suits suddenly burgeoned, and ready-to-wear makers responded with stylish costumes that were chic and affordable(Hill, 2004: 159).

Table 2. The 1910`s Swimsuits Analyses

\begin{tabular}{|c|c|c|}
\hline Kisalan kol bo & $\begin{array}{l}\text { The } \\
\text { model } \\
\text { properties }\end{array}$ & $\begin{array}{l}\text { The apron was replaced with a tunic that } \\
\text { covering the shorts and knickers.Even } \\
\text { though matching stockings were still worn, } \\
\text { bare legs were exposed from the bottom of } \\
\text { the trunks to the top of the shorts. } \\
\text { http://www.ocf.berkeley.edu and } \\
\text { http://www.britishpathe.com }\end{array}$ \\
\hline $\begin{array}{l}\text { Beyaz seritle } \\
\text { cervelenon } \\
\text { kenarlar }\end{array}$ & $\begin{array}{l}\text { The } \\
\text { fabric } \\
\text { properties }\end{array}$ & $\begin{array}{l}\text { The preferred fabric was still silk taffeta or } \\
\text { satin. In 1915, a new development in } \\
\text { knitting technology was about to change the } \\
\text { look and fit of swimwear for both women } \\
\text { and men. The skin tight, stretch suits were } \\
\text { an immediate success (Hill, 2004: 159). }\end{array}$ \\
\hline \multirow{2}{*}{ (Ozen, 2013:231) } & $\begin{array}{l}\text { The color } \\
\text { properties }\end{array}$ & $\begin{array}{l}\text { Black is no longer the color. These years we } \\
\text { could see the light colors such light blue } \\
\text { and light red in swimwear. }\end{array}$ \\
\hline & $\begin{array}{l}\text { The } \\
\text { accessory } \\
\text { properties }\end{array}$ & $\begin{array}{l}\text { Hats were still a must for women in public, } \\
\text { but the swim styles became more } \\
\text { functional, designed as rubberized turbans } \\
\text { and caps. } \\
\text { Also dark stockings and flat-soled bathing } \\
\text { shoes were used (Ozen, 2013:231). }\end{array}$ \\
\hline
\end{tabular}

Some sourses dedicated that modern swimwear was beganing at 1920`s and after world war I. these years women had achieved new levels of independence during the war, and 
fashions began to allow them more freedom of movement (Ward, 2005). After the privations of the war years, getting fit and healthy was a major priority. This meant lots of sports, swimming, sunbathing, and general outdoor activities. Sports had never been more popular, and the same went for the casual leisure clothing that was inspired by it (McEvoy, 2009: 85).

Table 3. The1920`s Swimsuits Analyses

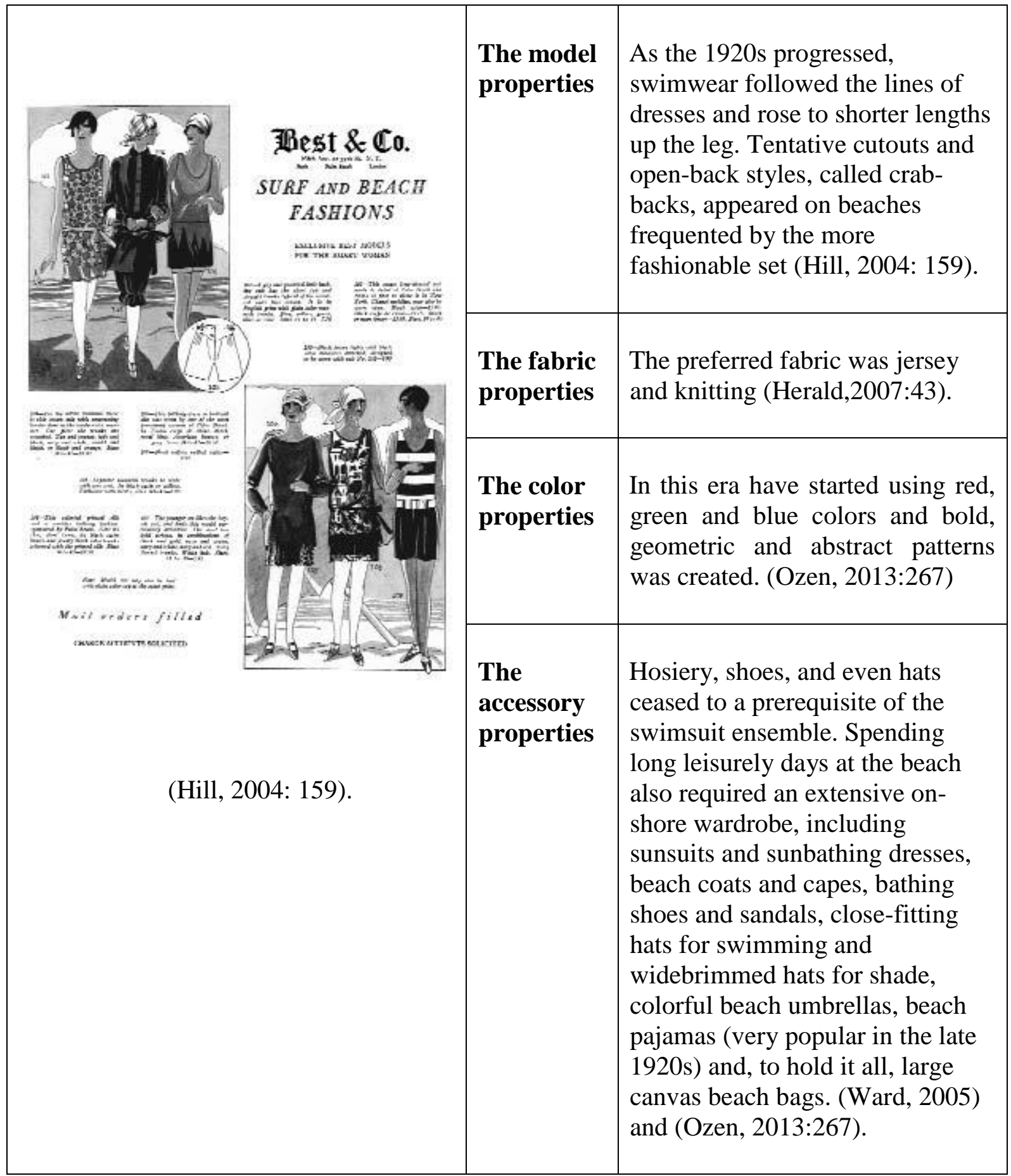


The evolution of swimwear in the 1930s continued the trend toward brevity and more exposure of skin. The 1930's began with a new generation of designers and the emergence of a new look for the body that was functional, sleek, and streamlined. The famous Bauhaus style was a beacon of the time, and void of all decoration and ornament. It left beauty up to form and function. This decade was characterized by four types of suits consisting of the Malliot, Sheath, Two-Piece, and the "Dressmaker." Of these, the Dressmaker became the enduring "staple" of the thirties. Its neck and shoulder line was borrowed directly from street wear and kept the skirt effect but shortened to a height above the knee (Ward, 2005).

Table 4. The 1930`s Swimsuits Analyses

\begin{tabular}{|c|c|c|}
\hline & $\begin{array}{l}\text { The } \\
\text { model } \\
\text { properties }\end{array}$ & $\begin{array}{l}\text { The one-piece maillot, with or without } \\
\text { a vestigial skirt or skirt front, was still } \\
\text { the most common style, but two-piece } \\
\text { suits, consisting of a high-waisted } \\
\text { skirt or trunks and a brassiere or halter } \\
\text { top, were introduced early in the } \\
\text { decade. }\end{array}$ \\
\hline 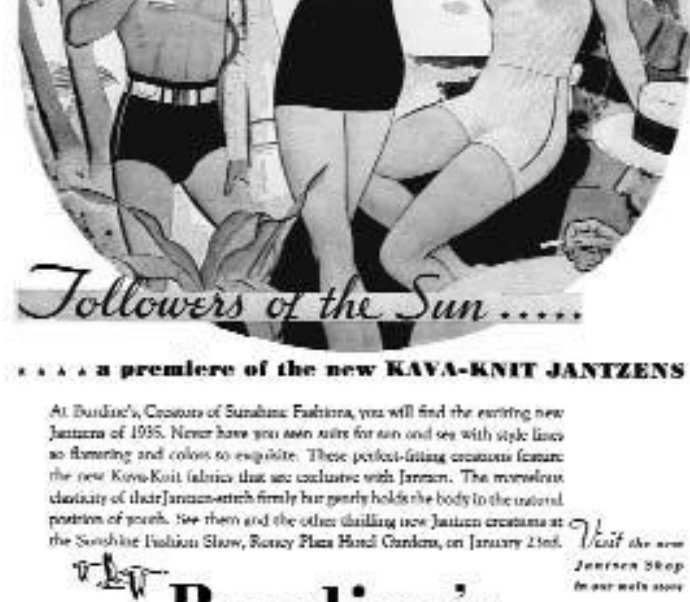 & $\begin{array}{l}\text { The } \\
\text { fabric } \\
\text { properties }\end{array}$ & $\begin{array}{l}\text { When feminine curves returned to } \\
\text { fashion around 1930, manufacturers } \\
\text { began to find ways of shaping the } \\
\text { body within the suit, using darts, } \\
\text { seaming, and strategically placed } \\
\text { elastic to uplift and emphasize the } \\
\text { bust. The most important innovation, } \\
\text { however, was Lastex, an elastic yarn } \\
\text { consisting of an extruded rubber core } \\
\text { covered in cotton, rayon, silk, acetate, } \\
\text { or wool, which was introduced in } \\
1931 \text { and soon revolutionized the } \\
\text { industry (Ward, 2005) }\end{array}$ \\
\hline (Hill, 2004: 160). & $\begin{array}{l}\text { The color } \\
\text { properties }\end{array}$ & $\begin{array}{l}\text { Nautical colors of navy and white, } \\
\text { with touches of bright red and tropical } \\
\text { prints seen in swimwear (Ward, 2005) } \\
\text { and (McEvoy, 2009: 64). }\end{array}$ \\
\hline & $\begin{array}{l}\text { The } \\
\text { accessory } \\
\text { properties }\end{array}$ & $\begin{array}{l}\text { A good outfit for a character by the } \\
\text { seaside or on a cruise is a pair of sailor } \\
\text { pants, flat-fronted and with a buttoned } \\
\text { panel, worn with a blueand- white top } \\
\text { or naval jacket with a jaunty straw hat } \\
\text { (McEvoy, 2009: 64). }\end{array}$ \\
\hline
\end{tabular}


With the interruption of fashion influences from Europe during the war years, American fashion makers took center stage. California ready-to-wear manufacturers especially moved into the limelight during the 1940s, led by the West Coast sportswear makers such as Cole, White Stag, and Koret. However, swimwear designs of the era did not present any notable innovation. The next leap in swimwear design occurred after the war and once again came from France. When Paris designer Louis Réard planned to launch a radical new swimsuit in 1946, he wanted to generate as much publicity as possible. He achieved this partially by calling the style the bikini, named for one of the nuclear test site islands then in the news. The scant, twopiece set actually received more debate and condemnation than the bomb tests had generated (Hill, 2004: 159), (http://www.ehow.com), (http://www.britishpathe.com).

Table 5. The 1940`s Swimsuits Analyses

\begin{tabular}{|c|c|c|}
\hline $\int_{-\infty}^{\infty x^{6}+\cdots}$ & $\begin{array}{l}\text { The model } \\
\text { properties }\end{array}$ & $\begin{array}{l}\text { The belly button was finally revealed in } \\
\text { bikini(two triangles of fabric on top cover } \\
\text { the woman's breasts and two triangles of } \\
\text { fabric on the bottom cover the groin and } \\
\text { the buttocks, leaving the woman's midriff } \\
\text { exposed) and led to a revolution in } \\
\text { women's bathing suits not seen since the } \\
\text { early 20th century } \\
\text { (http://www.examiner.com). }\end{array}$ \\
\hline 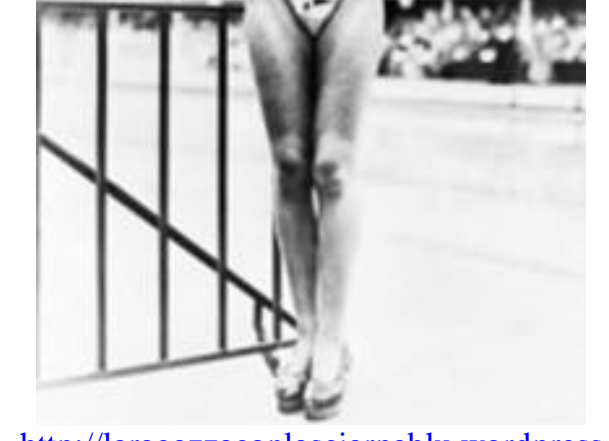 & $\begin{array}{l}\text { The fabric } \\
\text { properties }\end{array}$ & $\begin{array}{l}\text { The new technology in fibers brought } \\
\text { flexibility into the swim wear industry } \\
\text { itself and made it possible for stylistic } \\
\text { diversification and the creation of } \\
\text { specialized markets } \\
\text { (http://www.britishpathe.com). } \\
\text { In the mid-1940s, synthetic fibers such as } \\
\text { rayon, Lastex and Nylastic became staples } \\
\text { in swimwear design } \\
\text { (http://www.ehow.com). }\end{array}$ \\
\hline $\begin{array}{c}\text { http://laragazzaconlasciarpablu.wordpress } \\
. \text {.com }\end{array}$ & $\begin{array}{l}\text { The color } \\
\text { properties }\end{array}$ & $\begin{array}{l}\text { Swimwear manufacturers found design } \\
\text { inspiration in exotic locales such as } \\
\text { Mexico and Polynesia, and tropical print } \\
\text { and batik ensembles, worn with printed } \\
\text { cotton cover-ups and rustic accessories of } \\
\text { straw, wood, and raffia, were popular } \\
\text { throughout the decade. Exotic animals, } \\
\text { especially felines, were another popular } \\
\text { theme, as exemplified by the seductive } \\
\text { leopard-spotted suits of Cole of } \\
\text { California's "Female Animal" collection } \\
\text { (Ward, 2005). }\end{array}$ \\
\hline & $\begin{array}{l}\text { The } \\
\text { accessory } \\
\text { properties }\end{array}$ & $\begin{array}{l}\text { A wide variety of sunsuits, terry-cloth } \\
\text { robes, footwear, bathing caps, and } \\
\text { sunglasses, along with waterproof } \\
\text { makeup, allowed women to maintain a } \\
\text { polished appearance, both in and out of } \\
\text { the water (Ward, 2005). }\end{array}$ \\
\hline
\end{tabular}


The new suits in 1950`s featured pointed breasts and slim waists. Helped by the "Merry Widow" corset and other radical developments in foundation garments, such as rubber elastic fibers fortified with boning, under-wiring, and doubled panels. The "constructed suit" was a milestone in the history of swimwear design featuring the capacity to control and glorify the woman's body. This "neo-Victorian" swimsuit was intended to transform women's bodies and bolster their self-esteem. By the mid 50's shorter shorts were in, often zipped on both sides to provide a better fit. Make-up and sunglasses had also become a necessity to complete the look of the beach going American female.http://www.britishpathe.com.

Table 6. The 1950`s Swimsuits Analyses

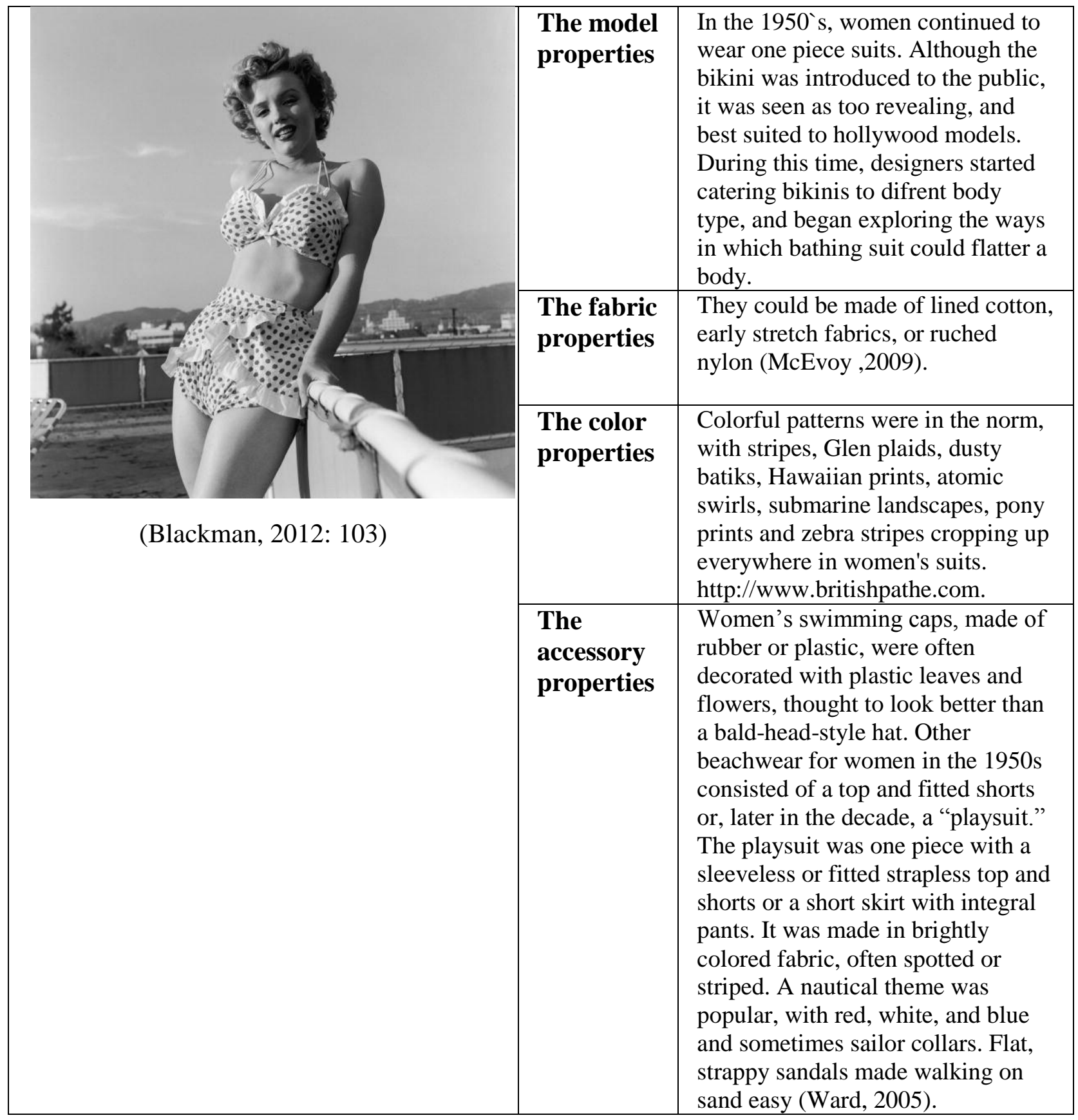


The Sixties was the decade that showcased the body, if nothing else. Swimwear design underwent another major revolution with the introduction of Spandex, a synthetic polyurethane fiber that made it ideal for a swimwear look that stressed shape, vibrant color, and a clingy silhouette. The use of Lycra allowed shaping and molding that resulted in a softer, rounder bosom and a greater style, reflective of the natural body. The "Nude Look" was popular, with the bosom bursting out of shrinking tops. To appease the more modest types, the "Convertible" bikini was the "Bikini with a conscience," an American innovation that was equipped with drawstrings or bows on the sides of the trunks and in the middle of the bra. This allowed the wearer to adjust the coverage to match taste and circumstances (http://www.britishpathe.com).

In 1964 designer Rudi Gernreich introduced a topless bathing suit called the monokini and in 1974 introduced the thong which was described as a "bottomless bathing suit". One piece maillot suits became popular, particularly after Farrah Fawcett's famous poster pose and in the movie "10" when Bo Derek ran down the beach wearing one. Another 70's style bathing suit was the string bikini (http://www.examiner.com), (Ward, 2005). 
Table 7. The 1960`s up 2000 Swimsuits Analyses

\begin{tabular}{|c|c|c|}
\hline$=18$ & $\begin{array}{l}\text { The } \\
\text { model } \\
\text { properties }\end{array}$ & $\begin{array}{l}\text { The bikini was invented in 1946, but it was } \\
\text { not adopted by most women until the 1960s. } \\
\text { Foreshadowing the bikini, the swimsuit } \\
\text { became briefer. From the mid-1960s, a mesh } \\
\text { panel in the sides or across the midriff or } \\
\text { cutouts under the arms became common. } \\
\text { Some swimsuits were essentially a two-piece } \\
\text { held together with plastic rings between the } \\
\text { top and bottom parts (McEvoy, 2009). }\end{array}$ \\
\hline $\begin{array}{c}\text { Myer. Women's Weekly Nov } \\
1977 .\end{array}$ & $\begin{array}{l}\text { The } \\
\text { fabric } \\
\text { properties }\end{array}$ & $\begin{array}{l}\text { Stretchy fabrics changed the look of } \\
\text { swimwear in the 1960s. The zipper } \\
\text { disappeared, and the swimsuit could simply } \\
\text { be pulled on(McEvoy, 2009). } \\
\text { The most important swimwear development, } \\
\text { however, was the availability of spandex, a } \\
\text { lightweight synthetic polyurethane fiber } \\
\text { much stronger and more elastic than rubber, } \\
\text { which was introduced for use in foundation } \\
\text { garments in 1958. Spandex expanded the } \\
\text { range of novelty fabrics available to } \\
\text { designers, and that meant suits could now be } \\
\text { made to fit like a second skin without heavy } \\
\text { linings and supporting layers (Ward, 2005). }\end{array}$ \\
\hline & $\begin{array}{l}\text { The color } \\
\text { properties }\end{array}$ & $\begin{array}{l}\text { Bright, solid colors and metallic finishes } \\
\text { were used. }\end{array}$ \\
\hline & $\begin{array}{l}\text { The } \\
\text { accessory } \\
\text { properties }\end{array}$ & $\begin{array}{l}\text { Accessories were necessary for the female } \\
\text { swimmer in the } 1960 \text { s. Swimming caps were } \\
\text { decorated with plastic flower petals or } \\
\text { designed with colorful stripes, seashells, } \\
\text { seahorses, butterflies or flower blossoms. } \\
\text { The caps were worn not only to help protect } \\
\text { the hair from the elements, such as sun and } \\
\text { chlorine. They were worn to coordinate with } \\
\text { the other swimwear accessories, such as terry } \\
\text { cloth onesies, beach coverups, beach bags, } \\
\text { beach dresses and shorts } \\
\text { (http://www.ehow.com). }\end{array}$ \\
\hline
\end{tabular}

In the 1980's a new "thigh high" cut for bathing suits was introduced by designer Norma Kamali. The suit consisted of high, inverted V cut over the hips reaching almost to the waistline and often combined with a deep V in front and/or back.In 1998 a new version of a two-piece, the tankini, had a tank-like top and separate bikini-like bottom was introduced. The tankini also introduced the concept of mix-and-match swimwear. Designer Anne Cole was the originator of this style. The tankini was hailed as the first major innovation in women's swimsuit design in several decades and quickly captured nearly a third of the swimwear market. Other versions are the camkini, a camisole style stop instead of tank top and the bandeaukini, or bandini, with a tube-like top (http://www.examiner.com), (Ward, 2005). 


\section{Conclusion}

Women's swim suits have always been at the fore front of modern contemporary fashion. In a constant state of metamorphosis as it changes according to the values of passing eras and the spirit of time. First introduced more as a cover-up for those daring enough to expose themselves to a quick dip in the water, the bathing suit is now a palette of colors and fabrics for everyone from the competitive swimmer to the consumate sun bather. There has been no end to the changing forms and functions and meanings of the bathing suit. In accordance with research and visual analysis, it proved that changing in model and materials of swimsuit has always reflected the zeitgeist.

\section{REFERENCES}

Blackman. C (2012). Modanin Tarihi. Istanbul: Kerasus.

Craik . J (1993). The Face Of Fashion (Culturel Studies In Fashion). London: Routledge.

Hemphill. S, Suk. J (2009). The Law, Culture And Economics Of Fashion. Stanford Law Review, Vol:61, March. USA.

HERALD. J (2007). FASHIONS OF DECADE (THE 1920s). England: Chelsea House Publishers.

HILL. D (2004). AS SEEN IN VOGUE. USA: TEXAS TECH UNIVERSITY PRESS.

FASHIONS OF DECADE (THE 1920s)

Hopkins, J (2012). Fashion Design, The Complet Guide. England: AVA Publishing.

Mcevoy. A (2009). C O S T U ME A N D F A S H I O N S O U R C E B O OK S

(The 1920s And 1930s). USA: Bailey Publishing.

Ozen, D (2013). Moda. Istanbul: Kaktus.

Ward. S (2005). ENCYLOPEDIA OF CLOTHING AND FASHION. USA: Thomson Gale Publishing.

Http://Www.Esamidterm2012.com

Http://Srmo.Sagepub.Com

Http://Www.Csulb.Edu

Http://Www.Fragrancex.Com

Http://Inventors.About.Com/Od

Http://Www.Smithsonianmag.Com

Http://Www.Ocf.Berkeley.Edu

Http://Www.Britishpathe.Com

Http://Www.Ehow.Com

Http://Www.Examiner.Com 